\title{
Baraboo Reads
}

\section{Treasa Bane}

\section{University of Wisconsin-Madison}

\begin{abstract}
After an incident of anti-Semitism occurring at the Baraboo (WI) High School, the Baraboo community initiated a Community Action Plan. Baraboo Reads, a collaborative effort between the University of Wisconsin-Platteville Baraboo Sauk County campus, Baraboo Public Library, Baraboo High School library, and middle school library, became a part of that action plan. As an academic librarian, I was involved in the planning, budgeting, and selection for Baraboo Reads. The Baraboo Reads was a complacent failure, but there is much to be learned about the impact of these types of incidents on small communities and how larger efforts toward inclusivity can be learned from such failures.
\end{abstract}

Keywords: anti-Semitism, community, diversity, book club, programming, failure

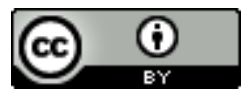

This is an Open Access article distributed under the terms of the Creative Commons Attribution 4.0 International License (http://creativecommons.org/licenses/by/4.0), which permits unrestricted use, distribution, and reproduction in any medium, provided the original work is properly cited. 


\section{Catalyst of Baraboo Reads}

On the morning of November 12, 2018, a photo of local Baraboo High School students raising their arms, signifying the Nazi salute, went viral on social media. A Twitter user posted a photo of the 2017 Junior class on prom night with the caption, referencing the Nazi salute, "We even got the black kid to throw it up \#barabooproud." Journalist Jules Suzdaltsev was embedded in the early investigation and conversation on Twitter. Gaining international attention, the Auschwitz Memorial official Twitter account also responded on Twitter (AuschwitzMuseum, 2018). Months later, BuzzFeed News Reporter Joseph Bernstein summarized the event and its effects in the article "The Baraboo Nazi Prom Photo Shocked the World. The City's Response Shocked Its Residents" (Bernstein 2019). Many expressed the need to condemn acts of ignorance, affirming our commitment to diversity and intolerance of hate, but the impact of those words had limited reach, and our Baraboo Reads program was no exception. Many of the initiatives, efforts, and responses that resulted from this incident were reactionary. This was exaggerated due to the high profile of the incident.

\section{History of the Campus-Community Relationship}

Some Baraboo community members aren't even aware of the campus's existence, which is up a hill and on the outskirts of town, but the campus's relationship with the community is long, once strong, and often tumultuous. The photo incident happened at the start of my second year as a professional librarian.

The consolidations and mergers this campus had endured in recent years resulted in an alltime low morale, and the campus had almost entirely lost its connection to the community. Everyone was working to keep doors open and butts in seats, which took time, money, and energy away from time going out into the community in order to maintain trusting relationships. 


\section{First Steps}

Before my time, the Baraboo campus library had a close relationship with the Baraboo Public Library. Not only did I wish to maintain this relationship because of its legacy, but it energized me. Working with other librarians in the community was the most fun I had during my two years of experience at UW-Platteville Baraboo Sauk County. The Baraboo Public Library staff were such gogetters, well organized, and wonderfully committed to serving the unique community of Baraboo.

The Baraboo Public Library staff and I had the same idea at almost the same time to start a community conversation through literature. The Baraboo Reads project members included Jessica Bergin, Baraboo Public Library Director; Lawrence Gillick, Baraboo High School Librarian; Kelly Steiner, Junior High Library Media Specialist; Penny Johnson, Teen Specialist at Baraboo Public Library; Carey Kipp, Youth Services Librarian at the Baraboo Public Library; Joan Wheeler, Adult Programming Librarian at Baraboo Public Library; and Jori Ruff, English Language Learning teacher K-12 Curriculum Leader for the Baraboo school district. Rather than spark further conversation about our collective, particular incident, we as librarians saw the value in seeking literature about other perspectives, other communities, and other incidents for others to draw their own parallels, or to think about our situation differently. Our mission stated the following:

Bringing our community together to learn and grow through reading and discussion on the topics of unity, equity, and inclusivity. Books selected will be from diverse perspectives and focus on the experiences of people of color, LGBTQ, people with disabilities, and other marginalized groups, as well as social issues such as immigration and poverty. 
While this nod to diversity for diversity's sake fit the mold of the Community Action Plan at large, its wide-as-possible scope, which is unattainable and problematic, pays lip service to the real goal of healing from the event. However, I've found that diversity initiatives often mean little if there isn't substantial understanding about what our actions and responses actually imply for all audiences, not just the audience we're addressing and not just the audience that was in attendance.

\section{Book Choice}

While at first we picked a title of related subject matter, we did not execute our selection as carefully as we could have. Every public library collection is a reflection of its community, and as members of that community, we would need to be hypercritical, which meant many things, but perhaps most importantly ensuring that the literature would have accurate representations drawn from a broad spectrum of gender identities and race groups rather than stereotypes. If we wanted to have discussions in April, and before the incident lost its heat, we wouldn't be able to get grant money within this time frame. Therefore, to speed up our process, we would ask for donations instead.

During the book selection process, we had to balance what was low cost, and what better suited our community's climate and situation. We chose The Gift of our Wounds: A Sikh and a Former White Supremacist Find Forgiveness After Hate, which is the true story of a former white supremacist, Arno Michaelis, befriending a Sikh, Pardeep Singh Kaleka. Pardeep was directly impacted by an attack on a Sikh Temple in Milwaukee by another white supremacist, Wade Michael Page. Both Pardeep and Arno grew up in Milwaukee, and discover through their friendship some surprising common ground. This was a decent choice for the Baraboo community because of the location of events in Wisconsin, and the book balances attempts at understanding misguidance and hate as well as forgiveness. 


\section{Timing, Promotion, and Planning}

The Baraboo Public Library youth librarians had many programs and a strong relationship with the local homeschooled community, which was a sizable part of the youth population in Baraboo. This helped our cause for promotion. Additionally, the high schools and middle schools encouraged their student book clubs to read the selected books from our program. Jori Ruff invited the members of the Social Equity Workgroup for the school district, who are part of the Ho-Chunk Education initiative, to engage with Baraboo Reads as well. This caused members of the Ho-Chunk Nation in Black River Falls, a nearby community also on Ho-Chunk land, to include our book selections in their middle school and high school talking circles. The Baraboo Public Library kept in close communications with the Baraboo Senior Center and the circulation supervisor at Baraboo Public Library who facilitates a book group. Jessica Bergin was also instrumental in partnering with other groups and organizations in the Baraboo community.

The Baraboo Public Library and the University of Wisconsin-Platteville Baraboo Sauk County campus created Facebook events. The Baraboo Public Library went the extra mile and did a paid advertising boost for it, which resulted in gained traction. Joan Wheeler created and sent out a press release. And of course, we appeared in the local newspaper a handful of times (Endres, 2019). Several of us on the planning committee were "site coordinators" for the libraries we were employed in. The libraries' partnership was meant to pull together ideas and resources. Our goals were to set in place a plan for discussion events, but the events themselves, each taking place within our own individual libraries, would look very different, as we each planned our own talking points and approaches. There could have been more overlap, but the idea was that the patron could visit more than one discussion session and have different experiences. 
I take responsibility for my own shortcomings during the Baraboo Reads initiative between my campus community and I, and the campus's connection to the greater community. The Baraboo Public Library, the Baraboo High School, and the Baraboo Middle School worked hard to make sure events were well attended and received. While I wouldn't say my part of the project was a failure in comparison, I think this piece exemplifies how strained relationships within the campus and the struggle for the campus to maintain its connection to the community impacted greater outreach and programming efforts. By the time I informed faculty and instructional staff via email and through personal correspondence, I knew it was too close to the beginning of the semester for them to plan it into their course curriculum. However, I convinced one faculty member to make it an extra credit opportunity. I encouraged faculty to encourage students to pick up a free copy of the book at our campus library during meetings I regularly attended, but these attempts were largely unsuccessful. My selection of two discussion meetings, each taking place on Thursdays one week apart, also turned out to be poor choices.

At the first campus book discussion, one community member attended. No one from campus attended. My one attendee and I had an invigorating conversation. He was a boomer, once a Baraboo lecturer, and a character who had lived in Baraboo for most of his life. He was craving a dialogue about the incident and about other issues in our community, and expressed such appreciation that these discussion events were made available. I think we both took something away about the book we hadn't recognized because there were many differences between us, which in many ways yielded a successful book discussion.

One of the Baraboo Public Library's discussion events had an attendance of around 25 people. This was facilitated by Jori Ruff, English Language Learning Teacher and K-12 Curriculum Leader with 
the Baraboo School District. Ruff was an outstanding instigator of conversation without censoring the attendees. The discussion group included people who regularly attended Baraboo Public Library's Lit Wits book group for mature readers, several from the Readers Anonymous book club for readers in their 20 s and 30s, and a few people from the community not associated with our regular book discussions. A few of the latter group had already participated in the book discussion at the Baraboo Senior Center, in which nine people had attended but wanted to discuss the book further. Lawrence Gillick attended this public library book discussion, as well as most of the events from the community action plan. Gillick felt uplifted by both the public librarians and this collaborative effort, but also by the community's support for educators at the high school who are trying their best in the aftermath of the controversy.

The high school librarian's discussions at the Baraboo High School had five students participate in the book discussions; they were mostly seniors who were members of an existing book club, but a few were also independently interested students and community members. Gillick acknowledged that the high school and public library discussions consisted of perspectives that were already in line with the mission of being more inclusive. We both were in agreement that if we had complete control over these programs, we would have pushed participants to be more critical and questioning of opposing perspectives and why they exist. Doing this, which would have involved navigating "sides" while trying not to pressure others into one way of thinking, would have been difficult and uncomfortable, and the results unpredictable; in short, this was not the intention of this community action plan at large, which was almost more about denial and hope, rather than facing truth. Not only was time against us in terms of presenting a more realistic representation of those involved, but speaking with the high school librarian reminded me that we were just a small part of the 
action plan, and trying to disrupt the meaning of the mission would have put us against the community's leaders.

The high school librarian said the discussions had the most positive impact on individuals who were on the fringe or who weren't sure how they felt about the incident, and there's hope that this would have a ripple effect, in which these individuals would take this knowledge to others on the fringe who probably didn't feel comfortable or welcome to attend the community events. Because of low attendance and a campus event taking place the next week, I decided to cancel my campus's second book discussion.

\section{Conclusions}

There is nothing wrong with any institution or organization emphasizing their welcoming environment or their support of lifelong learning or of diversity and inclusion. However, these assertions must have actions behind them. Baraboo's Community Action Plan had a lack of critical selfreflection following every event. The events were largely attended by the same community members who represented the white majority of Baraboo.

I could have encouraged better planning during the Baraboo Reads project, and I could have exerted more outreach within my own campus community. Our community needed to reconnect with each other and learn from each other. Having only one attendee at my book discussion was useful and thought provoking, but it could it have been more effective for more people. What I kept bumping into in several diversity initiatives was, how do you encourage those who would not be interested to show up? That is the million-dollar question if "diversity and inclusion" has any real goal. I believe this is what was meant in the public library discussions as well in terms of what one-on-one interactions and intervention could do for the Baraboo community. 
I cannot call Baraboo Reads a success. I learned a lot about my own expectations for programming on a small campus and also the widespread reach restructuring and financial struggles has not only on the campus and within the library but also with a campus library's relationship to the community. The issue with the Big Read my first year was that someone from another community was telling us how to conduct our programs without knowing what the parties' relationships, but we navigated our relationships, built on them, and made the Big Read our own and for Baraboo. The issue with Baraboo Reads was that, while we were collaborating more cohesively and coherently, there were many more hands, and we conformed to the vision of community leaders instead of developing our own.

The Baraboo Reads project members, sans myself, have been discussing whether to continue Baraboo Reads. However, the Baraboo Public Library will have other urgent priorities as it undertakes a major expansion project. In terms of the greater Community Action Plan, many of us have doubts that this will go beyond the events that have already happened. My cynicism tells me this is because handson action was never the goal, especially as the heat of the incident and public exposure has cooled down.

\section{References}

AuschwitzMuseum. 2018. "It is so hard to find words... This is why every single day we work hard to educate. We need to explain what is the danger of hateful ideology rising. Auschwitz with its gas chambers was at the very end of the long process of normalizing and accommodating hatred." [Twitter Post]. Retrieved from https://twitter.com/AuschwitzMuseum/status/1061936276402782209?s=20. 
Bernstein, J. 2019. "The Baraboo Nazi Prom Photo that Shocked the World. The City's Response Shocked Its Residents." Buzzfeed. Retrieved from https://www.buzzfeednews.com/article/josephbernstein/baraboo-nazi-prom-photo

Endres, Susan. 2019. "Baraboo libraries collaborate to offer community book discussions based on inclusivity." Baraboo News Republic. Retrieved from https://www.wiscnews.com/baraboonewsrepublic/news/local/baraboo-libraries-collaborateto-offer-community-book-discussions-based-on/article da592791-39c7-59ff-a8c664e462a80f0a.html 